\title{
The Forward Exchange Rate Unbiasedness Hypothesis: A Single Break Unit Root and Cointegration Analysis
}

\author{
Michael E. Mazur, Miguel D. Ramirez \\ Department of Economics, Trinity College, Hartford, USA \\ Email: miguel.ramirez@trincoll.edu,mmazur@trincoll.edu \\ Received July 20, 2013; revised August 20, 2013; accepted August 31, 2013
}

Copyright (C) 2013 Michael E. Mazur, Miguel D. Ramirez. This is an open access article distributed under the Creative Commons Attribution License, which permits unrestricted use, distribution, and reproduction in any medium, provided the original work is properly cited.

\begin{abstract}
In an age of globalized finance, Forex market efficiency is particularly relevant as agents engage in arbitrage opportunities across international markets. This study tests the forward exchange rate unbiasedness hypothesis using more powerful tests such as the Zivot-Andrews single-break unit root and the KPSS stationarity (no unit root) tests to confirm that the USD/EUR spot and three-month forward rates are I(1) in nature. The study successfully employs the Engle-Granger cointegration analysis which identifies a stable long-run relationship between the spot and forward rates and generates an ECM model that is used to forecast the in-sample (historical) data. The study's findings refute past conclusions that fail to identify the data's I(1) nature and suggest that market efficiency is present in the long run but not necessarily in the short run.
\end{abstract}

Keywords: Cointegration Analysis; Error-Correction Model (ECM); Forward Exchange Rate Unbiasedness Hypothesis (FRUH); KPSS No Unit Root Test; Unexploited Profits; Zivot-Andrews Single Break Unit Root Test

\section{Introduction}

This paper investigates the validity of the forward exchange rate unbiasedness hypothesis (FRUH) which is indicative of efficiency in the foreign exchange market using more powerful unit root and no unit root tests. The study employs the single break unit root and cointegration analysis to determine whether a stable long-run relationship between the USD/EUR spot and forward exchange rates exits, and generates an error correction model to examine further the dynamics of market efficiency. The paper is organized as follows. First, a brief discussion of the relevant literature and a conceptual framework of analyses are presented. Next, the nature of the data and variables is discussed. The third section presents and analyzes the results, while the last section summarizes the main findings in the paper.

\section{Conceptual Framework}

A multitude of econometric studies have explored the FRUH which suggests that the forward foreign exchange rate serves as an unbiased predictor of the future spot rate. A review of the economic literature surrounding foreign exchange market efficiency yields largely contradictory results with both rejections and confirmations of the hypothesis. By and large, methodological and empirical challenges are at the root of the contradictory results surrounding this important topic in international finance. While early studies disproportionately accepted the FRUH, the findings are increasingly passé for failure to consider the non-stationary nature of the economic data (see [1,2]). Recent studies that use unit-root and cointegration analysis increasingly reject the null hypothesis that the forward rate is an unbiased predictor of future spot rate (see [3-6]).

Given the equation $s_{t}=\alpha+\beta f_{t-3}+e_{t}$, confirmation of the FRUH requires that the future spot and forward rates are cointegrated with a vector of $(1,-1)$ and the coefficient $\alpha=0$ and $\beta=0$. Under market efficiency, the expected mean of the error term should equal zero and be independently identically distributed as a white-noise error term. Using the spot and three month forward rates, the same criteria must be met to satisfy the efficiency hypothesis. Although studies since Hakkio and Rush [7] generally consider the cointegrating relationship between $s_{t}$ and $f_{t-n}$ to explore the efficiency and accuracy of the forward in predicting the spot rate, Zivot [8] also suggests that the non-lagged variables should also share a 
cointegrating vector. Zivot argues that the latter model of cointegration more effectively captures the stylized facts of the exchange rate data and may supplement cointegration findings. However, the relationship between the spot and lagged forward rate is most important for this study. Related articles examining efficiency in the foreign exchange market look at changes in the future spot rate influenced by the forward risk premium. These cases primarily concern deficiencies in the rational expectations hypothesis, which are assumed when investigating the FRUH. Additionally, cointegration analysis warrants the exclusion of the risk premium from the model (see [9]).

The market efficiency hypothesis is based on the idea that participants in the FX market have rational expectations and are risk neutral. Expected returns on speculative currency investments should be zero in the long run (see [6]). With much of the growth in global finance driven by the acceleration and integration of short-term capital flows, market participants are significantly more exposed to foreign markets. Increasing engagement in foreign markets and the resulting financial growth are spurred by market liberalization, technological advances, and financial engineering (see [10]). Foreign exchange is an unavoidable facet of transacting in the global marketplace and the rejection of FRHU suggests there are opportunities to realize incremental returns on investments by engaging in FX market arbitrage. In an inefficient market, agents must exert caution in carefully implementing strategies to yield positive profits from speculative bubbles. The prospect of realizing gains in the FX market is equally valid to that of incurring losses (see [11]). By contrast, a failure to reject the null hypothesis in the long run suggests agents have rational expectations and are risk neutral, thus foreign currency holdings are only useful insofar as simplifying the process of purchasing securities abroad. If the market is efficient and all subjects have complete information, foreign exchange transactions should only yield a normal profit.

This study uses single break unit root and cointegration analysis to determine whether there is a stable underlying relationship between the future spot and forward exchange rates. Following the Engel-Granger cointegration framework, an error correction model is used to examine adjustment speed and efficiency in the presence of systemic shocks. The model takes the general form of $s_{t}=\alpha+\beta f_{t-3}+e_{t}$ with the $\$ / €$ spot and 3-month forward rates as the economic variables under investigation. Given the first order integration identified in section III, $s_{t}$ refers to the log of the spot rate and $f_{t-3}$ enotes the $\log$ of the three-month forward exchange rate. The USD/EUR rate is ideal for this study since the euro is the second most traded currency behind the US dollar. Additionally, the launch of the euro common currency on
January 1, 1999 marked one of the most monumental economic and political endeavors of the century. Eleven national currencies merged overnight to transform the world's currency market and the process of broadening the euro area continues to this day [10]. The eurozone comprises seventeen member states and there is a reasonable amount of data available to study the common currency. The euro spot and three-month forward rates are from the Haver data base which, in turn, obtained the data from the European Central Banks' Eurostat and London's Financial Times' collection. The spot and 3month forward $\$ / €$ exchange rates are measured as monthly averages for the period January 2000 to March 2013.

\section{Data}

The US dollar per euro spot rate is the model's dependent variable. For ease of interpretation, the variables are expressed in logarithmic form, so the estimated results reveal the spot rate's adjustment to systemic shocks as an elasticity. The log of the spot rate (dependent variable) is named USD_EUR and is measured as a monthly average and its first difference is referred to as $\mathrm{d} s_{t}$.

The independent variable is the three-month forward USD/EUR exchange rate measured as a monthly average for the period 2000M01 to 2013M03. The variable requires a logarithmic transformation for the error correction model. The $\log$ of the forward rate is called USD_EUR_3MO and its difference is referred to as $\mathrm{d} f$. The variable is lagged three periods in the model to explore its causal relationship. The expected coefficient assuming satisfaction of the FRUH is one. Most recent studies, however, have failed to find support for the FRUH (see [5]).

Dummy variables D1 and D2 are used in the error correction model to incorporate the structural breaks found in the data respectively for June of 2003 and September and October of 2008. Essentially, D1 and D2 account for periods of macro-instability that disrupt the currency markets.

\section{Estimation Results}

The log of the spot rate in level form and first differences is plotted, respectively, in Figures 1(a) and (b) to provide preliminary insights before unit root and cointegration analysis. The level and first difference graphs clearly reveal the integrated nature of the data. The series exhibit clear positive drift in level form and differencing eliminates many of the data's non-stationary properties. ADF, KPSS, and Zivot-Andrews [12] single break point tests further confirm the nature of this process, but economic theory and time series literature support the expectation of an I(1) process. 
USD_EUR

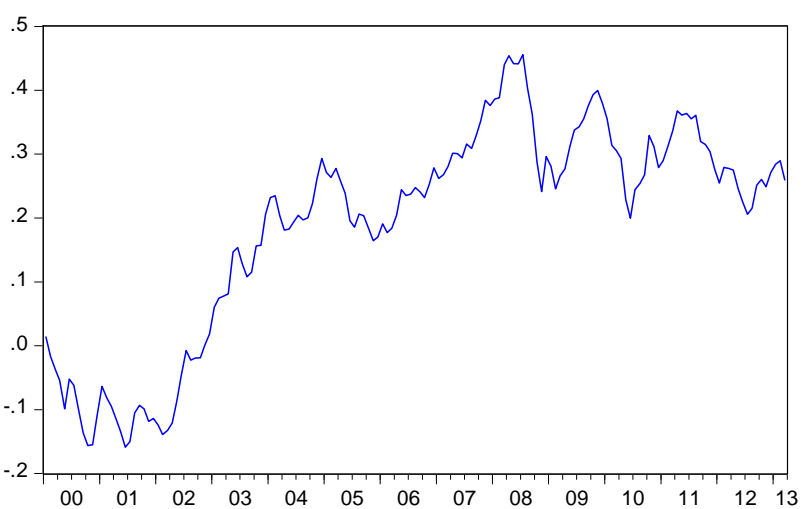

(a)

$\mathrm{S}$

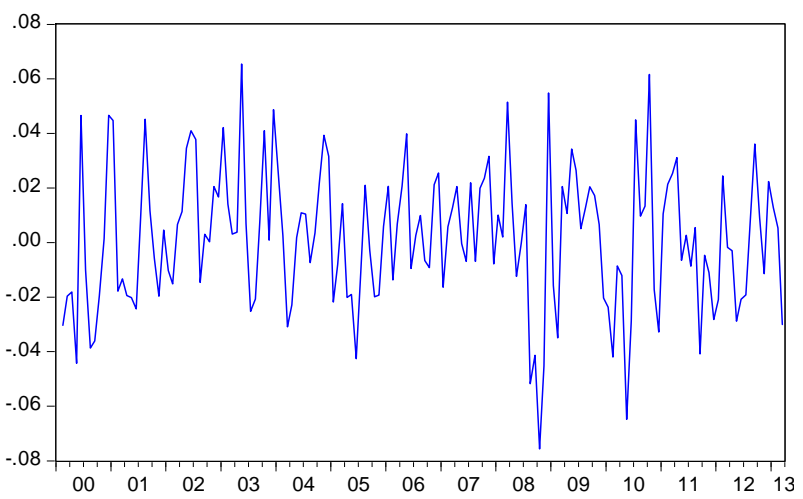

(b)

Figure 1. (a) Level Data; (b) Differenced Data.

Similar to the spot rate series, the level and first difference plots of the three-month forward rate series visually reveal the integrated nature of the data. Positive drifts in level form are corrected through differencing and the series are rendered more stationary in Figures 2(a) and (b).

The admittedly low-powered Augmented DickeyFuller test is the first test used to identify a unit root in the spot rate series. The Doldado-Sosvilla methodology suggests an initial test including both a trend and intercept and subsequent tests eliminating insignificant exogenous regressors. The ADF t-statistic for a unit root is $(-0.596397)$ as shown in Table 1 below. Since the t-stat is insignificant at all levels, the null hypothesis of a unit root cannot be rejected. ADF tests for $\mathrm{d} s_{t}$, the differenced spot rate, reveal that the ADF $t$-stat $(-11.44760)$ is significantly beyond the $1 \%$ level. This permits rejection of the unit root null hypothesis for the differenced series and conclusion that USD_EUR is an I(1) process.

An Augmented Dickey Fuller test for the three-month forward rate shows that the series has a unit root and is non-stationary in level form without a significant trend or intercept. The ADF test statistic of $(-1.593227)$ in Table
USD EUR $3 M O$

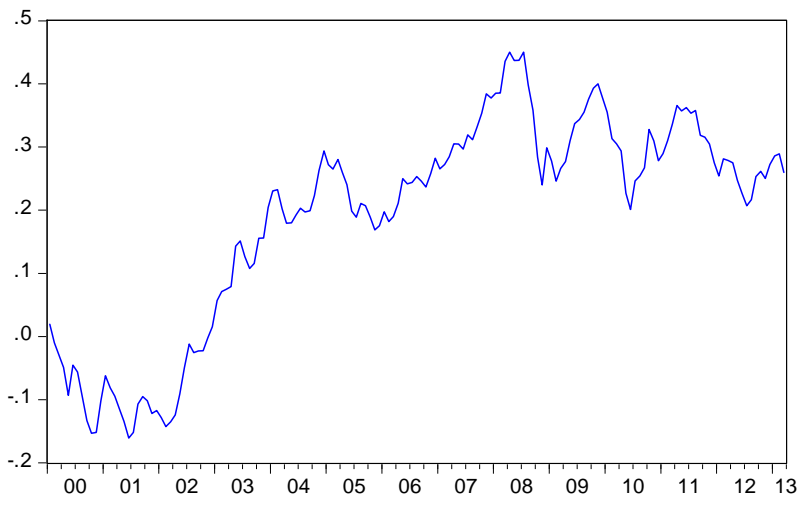

(a)

$\mathrm{F}$

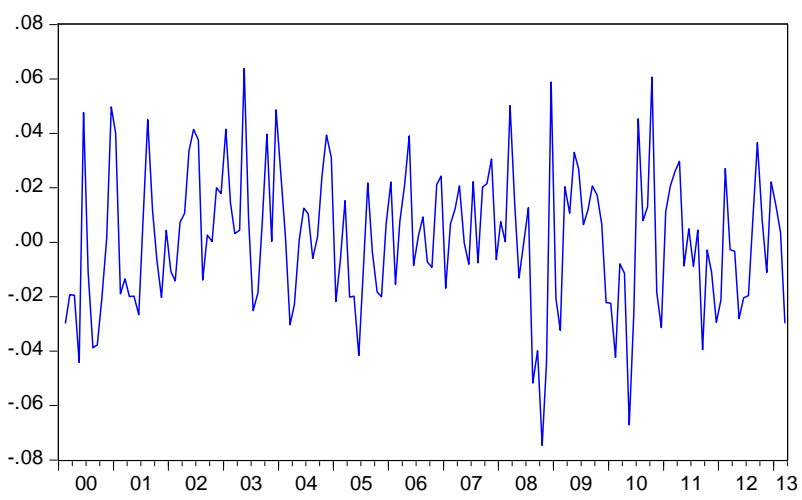

(b)

Figure 2. (a) Level Data; (b) Difference Data.

Table 1. USD/EUR: Augmented Dickey Fuller unit root tests for stationarity, sample period 2000-2013.

\begin{tabular}{ccccc}
\hline \multicolumn{4}{c}{ Variables } & \multicolumn{4}{c}{ Levels First Difference $5 \%$} & Critical Value & 1\% Critical Value \\
\hline $\mathrm{S}$ & -0.596 & -11.448 & -1.943 & -2.580 \\
$\mathrm{~F}$ & -1.593 & -9.200 & -2.880 & -3.472 \\
\hline
\end{tabular}

$\mathbf{1}$ is insignificant and we cannot reject null hypothesis. The differenced series' significant t-statistic of $(-9.200284)$ is significantly beyond the $1 \%$ level. Thus, the results reported reject the null hypothesis and suggest the level series is an I(1) process that must be differenced to achieve the stationarity required for modeling.

The Kwiatkowski-Phillips-Schmidt-Shin [13] Lagrange Multiplier unit root test is a more powerful test designed to confirm the finding that the spot rate is an $\mathrm{I}(1)$ process. The KPSS test on the level data reports a test-statistic of (0.294096). As shown in Table 2. Since the LM-statistic is greater than the 0.216 critical value at the $1 \%$ confidence level, the null hypothesis of stationarityis rejected for the level series. This supports the ADF findings of a unit root in level form. The KPSS LM-test results for the differenced series yields insignificant evi- 
Table 2. USD/EUR: Kwiatkowski-Phillips-Schmidt-Shin Lagrange Multiplier unit root test, sample period 20002013.

\begin{tabular}{|c|c|c|c|c|}
\hline Variables & \multicolumn{4}{|c|}{ Levels First Difference 5\% Critical Value 1\% Critical Value } \\
\hline $\mathrm{S}$ & 0.294 & 0.0798 & 0.146 & 0.216 \\
\hline $\mathrm{F}$ & 0.296 & 0.0831 & 0.146 & 0.216 \\
\hline
\end{tabular}

dence to reject the null of stationarity. Again, these findings confirm the ADF results with greater power.

The same high power test is used to confirm that the logged three-month forward exchange rate is an I(1) process as suggested by the ADF. The null hypothesis of stationary in level form can be rejected at the $1 \%$ significance level based on the LM-test results represented in Table 2 and 2.1(b) of the appendix. This finding provides further credibility to support the conclusion from the ADF test that the series has a unit root. A KPSS test of the first difference reveals that $\mathrm{d} f_{t}$ is a stationary process. The null hypothesis of stationarity cannot be rejected for the series' first difference, therefore USD_EUR $3 \mathrm{MO}$ is an integrated order one process.

The Zivot-Andrew single breakpoint test is another method for detecting unit roots in the presence of a single structural break in the data series. Conventional unit root tests have relatively low power when the stationary alternative is true and a structural break in the data is ignored. In other words, investigators are more likely to conclude incorrectly that the series is non-stationary when a structural break is ignored (see [14]). Following the lead of Perron, most investigators report estimates for either models A and C, but in a relatively recent study Seton [15] has shown that the loss in test power $(1-\beta)$ is considerable when the correct model is $\mathrm{C}$ and researchers erroneously assume that the break-point occurs according to model A. On the other hand, the loss of power is minimal if the break date is correctly characterized by model A but investigators erroneously use model $\mathrm{C}$.

Performing the test on the spot and forward rates using model $\mathrm{C}$ reveals significant results. The first tests in Table 3 and 3.1 of the appendix are significant and do not allow for the rejection of the null hypothesis. This suggests that the series contains both a unit root and a structural break at 2008M08. A break at that point makes logical sense given the start of the US subprime mortgage crisis. The use of model $\mathrm{C}$ also provides highly significant results with a failure to reject the presence of a unit root. When using the differenced series for the spot and forward rates, a structural break is also detected at 2003M06 using model C, which coincides with the peak in unemployment following the early 2000's recession and escalating conflict in Iraq. The unexpected cost of rebuilding a stable government capable of self-rule from the rubble of Saddam Hussein's regime was not an out
Table 3. Zivot-Andrews unit root test.

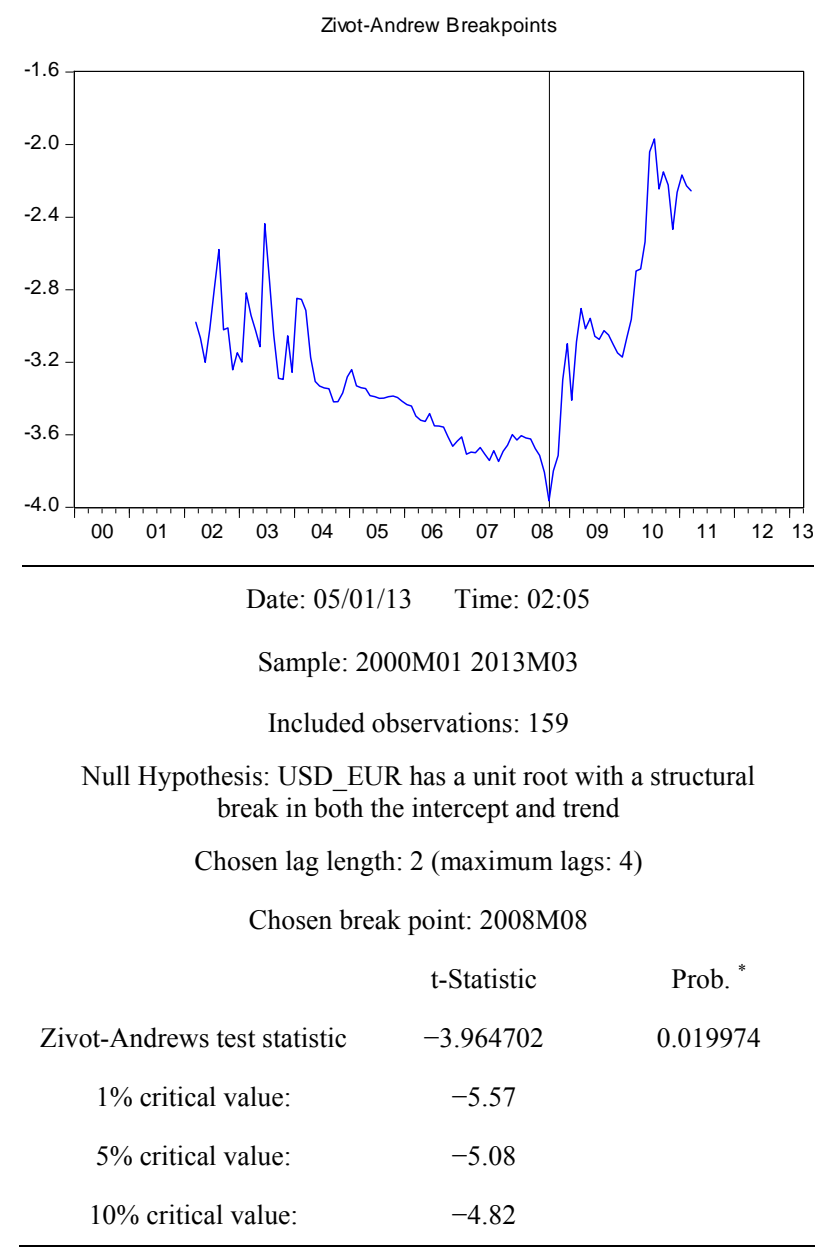

come or obligation the US foresaw.

Dummy variables are therefore incorporated into the model for both of these breaks. Although the financial crisis was already mounting for some time, the unexpected declaration of bankruptcy by Lehman Brothers in September of 2008 marked both the intensification of the U.S. recession and the crisis in world financial markets. Additionally President Bush gave his "Mission Accomplished" speech on the May $1^{\text {st }}$ but by June insurgent attacks were intensifying and it was becoming clear that the mission in Iraq would be far more difficult and costly than ever imagined.

Given that both the dependent and independent variables are I(1), the Engle-Granger cointegration test procedure requires an ADF test of the residuals(without intercept and trend) of the Forex equation in level form. An ordinary least squares regression is generated using the $\log$ of level series for the equation $s_{t}=\alpha+\beta f_{t-3}+e_{t}$ in appendix Table 4.1. As suggested by Zivot [8], the same procedure is conducted for the $s_{t}=\alpha+\beta f t+e_{t}$ equation which is represented in Table 4.2. Augmented Dickey-Fuller unit root tests are performed on both sets 
of residuals in Tables 4.1(b) and 4.2(b) of the appendix. The results for the residuals including the lagged term overwhelmingly support the rejection of the null hypothesis of a unit root for all significance levels. The test in simple form is less significant but the t-statistics are still strong enough to reject the null of a unit root at the $5 \%$ level of significance. The stationary nature of the residuals in level form suggests that $s_{t}$ is cointegrated with both $f_{t-3}$ and $f$. The identification of a cointegrating vector is important in that it identifies a stable long-run relationship that keeps the variables in proportion over time, and suggests that the market is efficient in the long run. Following the Engle-Granger representation theorem, an error correction model that includes the residuals is generated to reconcile the short and long-run behavior of the underlying relationship between the forward and spot exchange rates.

The final model shown in Model 1 is significant and with a high degree of explanatory and forecasting power. The error correction model incorporates the forward vaable, error correction term, and two dummy variables: D1 for 2003M06 and D2 for 2008M09-M10 described above. The HAC Newey-West [16] procedure was utiled in estimating the ECM, thus correcting the OLS stanrd errors for both autocorrelation and heteroscedasticity. The Durbin Watson test statistic is 2.1 and suggests that the final model does not suffer from first order serial correlation. All of the terms except for the constant gen-

Model 1. USD/EUR: Error Correction Model; dependent variable is: $(S), 2000-2013$.

\begin{tabular}{|c|c|c|c|c|}
\hline \multicolumn{5}{|c|}{ OLS Regressions } \\
\hline Variable & Coefficient & Std. Error & t-Statistic & Prob. \\
\hline $\mathrm{C}$ & $5.87 \mathrm{E}-05$ & $6.93 \mathrm{E}-05$ & 0.846956 & 0.3984 \\
\hline $\mathrm{F}$ & 1.001182 & 0.003877 & 258.2166 & 0.0000 \\
\hline $\operatorname{EC} 1(-1)$ & -0.046752 & 0.021973 & -2.127676 & 0.0350 \\
\hline D1 & -0.001047 & 0.000250 & -4.182255 & 0.0000 \\
\hline D2 & -0.001122 & 0.000310 & -3.619541 & 0.0004 \\
\hline $\operatorname{AR}(1)$ & -0.288958 & 0.092038 & -3.139549 & 0.0020 \\
\hline R-squared & 0.998 & \multicolumn{2}{|c|}{ Mean dependent var } & 0.002 \\
\hline Adjusted R-squared & 0.998 & \multicolumn{2}{|c|}{ S.D. dependent var } & 0.025 \\
\hline S.E. of regression & 0.001 & \multicolumn{2}{|c|}{ Akaike info criterion } & -10.611 \\
\hline Sum squared resid & 0.000 & \multicolumn{2}{|c|}{ Schwarz criterion } & -10.495 \\
\hline Log likelihood & 838.994 & \multicolumn{2}{|c|}{ Hannan-Quinn criter. } & -10.564 \\
\hline F-statistic & 14495.59 & \multicolumn{2}{|c|}{ Durbin-Watson stat } & 2.100 \\
\hline Prob(F-statistic) & 0.000 & & & \\
\hline
\end{tabular}

ate high t-statistics and are significant at the 5\% significance level. The $\mathrm{EC} 1(-1)$ term is significant at the $5 \%$ level and suggests that a deviation of 10 percent from the long run equilibrium during the current period is corrected in the subsequent period by approximately 0.5 percent. The addition of the D2 term, given that its inclusion makes theoretical sense, increases the Adjusted $\mathrm{R}$ squared and enhances the degree of accuracy for the final model.

The fact that the constant is not significantly different from zero supports the efficiency hypothesis.

The estimated coefficient for the forward rate is 1.001182 with a $t$-stat of 258.2166 . This result is highly significant and since it is close to 1 , the model fulfills the FRUH criteria. The failure to reject the null hypothesis serves to support the use of the forward rate as an unbiased estimator of the future spot rate. The evidence for the dollar-euro rate suggests support for market efficiency in the long run but not necessarily in the short run because a disequilibrium exists between the two variables, suggesting that expected returns to speculators are not zero in the short run (see [7]). In general, the results suggest that participants in the foreign exchange market are risk neutral and have little to gain from speculation in the long run.

EC models were also used to track the historical data on the percentage change in the spot rate for the period under review. Figure 3 below shows that the model was able to track the turning points in the actual series quite well. $s$ refers to the actual series and ( $\mathrm{sf}$ ) denotes the in-sample forecast. In addition, Figure 4 below shows that the Theil inequality coefficient for this model is 0.02270 , which is well below the threshold value of 0.3 , and suggests that the predictive power of the model is quite good (see [17]). The Theil coefficients can be decomposed into three major components: the bias, variance, and covariance terms. Ideally, the bias and variance components should equal zero, while the covariance

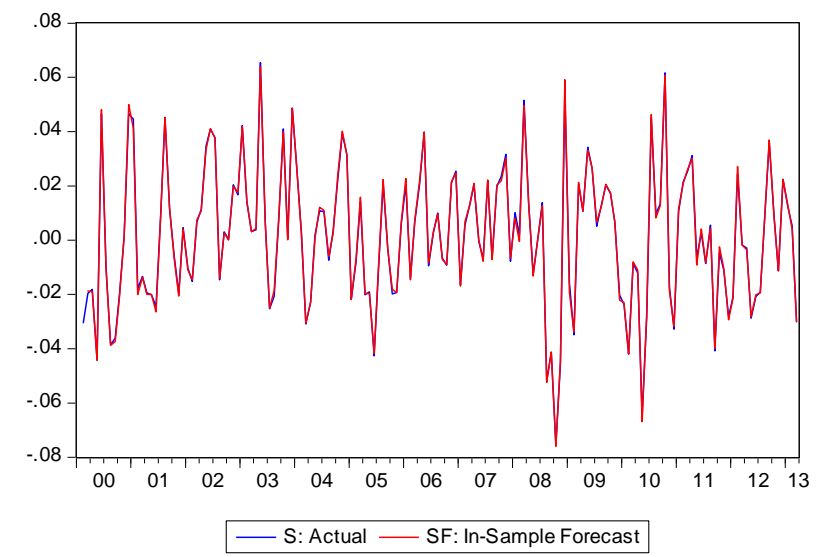

Figure 3. Actual and simulated percentage changes in the spot rate. 


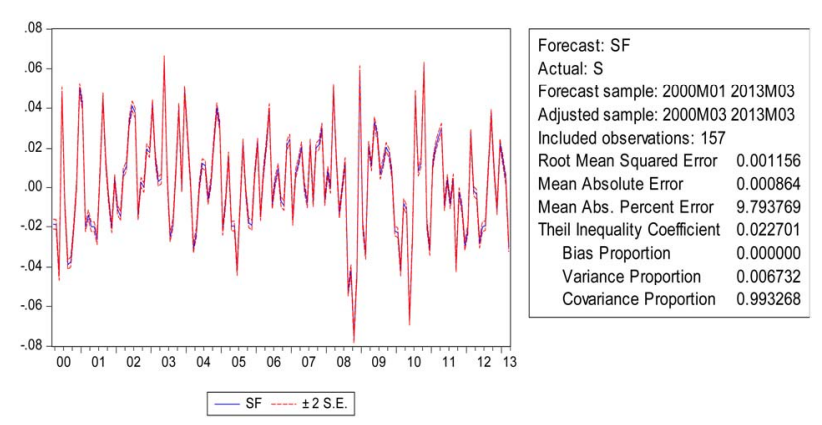

Figure 4. Theil inequality coefficient for in-sample forecast.

proportion should equal one. The reported estimates suggest that all of these ratios are close to their optimum values (bias $=0.0000$, variance $=0.0067$, and covariance $=0.9932$ ). Sensitivity analysis on the coefficients also revealed that changes in the initial or ending period did not alter the predictive power of the selected models (results are available upon request).

\section{Conclusion}

Efficiency in the foreign exchange market is especially relevant in the world of globalized finance since market agents are frequently and increasingly transacting both at home and abroad. This study shows that the spot and three-month forward exchange rates are I(1) processes using the more powerful KPPS stationarity test and the Zivot Andrews single break unit root test. Following the Engle-Granger cointegration analysis framework, a longrun stable relationship between the three-month forward exchange rate and the future spot rate is identified which suggests that the forward rate contains useful information about the spot rate; in other words, it supports market efficiency in the long run. Insofar as the error correction model is concerned, it provided further support for the forward exchange rate unbiasedness hypothesis. With a high degree of power, the results of the model fulfill the final two criteria for market efficiency, viz., a constant equal to 0 and a coefficient of 1 . However, the results also suggest that there is a disequilibrium in the short run that is only partially corrected in subsequent periods, suggesting that, in the short run, there might be unexploited profit opportunities for speculators and/or a timevarying risk premium. Needless to say, economists have debated the issue of exchange market efficiency since the 70 's and this study, although supportive of market efficiency in the long run, will by no means settle the controversy. Finally, the endogenously determined structural breaks in the data indicate that, since the common currency's inception, volatility and disruption of the Forex market have been generated by both the un-expected costs associated with the war in Iraq and the 2008 global financial crisis.

\section{REFERENCES}

[1] R. M. Levich, "Empirical Studies of Exchange Rates, Price Behavior, Rate Determination, and Market Efficiency," In: R. W. Jones and P. B. Kennen, Eds., Handbook of International Economics, Vol. II, Elsevier, Amsterdam, 1978, pp. 979-1040.

[2] J. A. Frenkel, "Flexible Exchange Rates, Prices, and the Role of News: Lessons from the 1970s," In: R. A. Batchelor and G. E. Wood, Eds., Exchange Rate Policy, Macmillan, London, 1982.

[3] R. E. Cumby and M. Obstfeld, "International Interest Rate and Price Level Linkages under Flexible Exchange Rates: A Review of the Evidence," 1984.

[4] C. Engel, "The Forward Discount Anomaly and the Risk Premium: A Survey of Recent Evidence," Journal of Empirical Finance, Vol. 3, No. 2, 1996, pp. 123-192.

[5] J. Olmo and K. Pilbeam, "Uncovered Interest Parity and the Efficiency of the Foreign Exchange Market: A Reexamination of the Evidence," International Journal of Finance and Economics, Vol. 16, No. 2, 2011, pp. 189204. doi:10.1002/ijfe.429

[6] V. Ukpolo, "Exchange Rate Market Efficiency; Further Evidence from Cointegration Tests," Applied Economics Letters, Vol. 2, No. 6, 1995, pp. 196-198. doi:10.1080/135048595357438

[7] C. S. Hakkio and M. Rush, "Cointegration: How Short Is the Long Run?" Journal of International Money and Finance, Vol. 10, No. 4, 1991, pp. 571-581. doi:10.1016/0261-5606(91)90008-8

[8] E. Zivot, "Cointegration and Forward and Spot Exchange Rate Regressions," 1998.

http://128.118.178.162/eps/em/papers/9812/9812001.pdf

[9] M. Kuhl, "Cointegration in the Foreign Exchange Market and Market Efficiency since the Introduction of the Euro: Evidence Based on bivariate Cointegration Analyses," 2007.

[10] D. W. Duisenberg, "Recent Developments and Trends in World Financial Market," 2000.

http://www.ecb.int/press/key/date/2000/html/sp001114.en .html

[11] A. C. Jung and V. Wieland, "Forward Rates and Spot Rates in the European Monetary System-Forward Market Efficiency," Weltwirtschaftliches Archiv, Vol. 126, No. 4, 1990, pp. 615-629. doi:10.1007/BF02707471

[12] E. Zivot and D. Andrews, "Further Evidence of Great Crash, the Oil Price Shock, and Unit Root Hypothesis," Journal of Business and Economic Statistics, Vol. 10, No. 3, 1992, pp. 251-270. doi:10.1080/07350015.1992.10509904

[13] D. Kwaitkowski, P. C. B. Phillips, P. Schmidt and Y. Shin, "Testing the Null Hypothesis of Stationarity against the Alternative of a Unit Root," Journal of Econometrics, Vol. 54, No. 1-3, 1992, pp. 159-178. doi:10.1016/0304-4076(92)90104-Y

[14] P. Perron, "The Great Crash, the Oil Price Shock and the Unit Root Hypothesis," Econometrica, Vol. 57, No. 6, 1989, pp. 1361-1401. doi:10.2307/1913712

[15] A. Seton, "On Unit Root Tests when the Alternative Is a 
Trend Break Stationary Process," Journal Of Business and Economic Statistics, Vol. 21, No. 1, 2003, pp. 174184. doi:10.1198/073500102288618874

[16] W. K. Newey and K. West, "A Simple Positive SemiDefinite Heteroscedasticity and Autocorrelation Consistent Covariance Matrix," Econometrica, Vol. 55, No. 3,
1987, pp. 703-708. doi:10.2307/1913610

[17] H. Theil, "Applied Economic Forecasting," North-Holland, Amsterdam, 1966. 


\section{Appendix:}

\section{ADF Tests:}

Table 1.1.

Null Hypothesis: USD_EUR has a unit root

Exogenous: Constant, Linear Trend

Lag Length: 1 (Automatic-based on SIC, maxlag = 13)

\begin{tabular}{|c|c|c|c|c|}
\hline & & & t-Statistic & Prob. $^{*}$ \\
\hline \multicolumn{3}{|c|}{ Augmented Dickey-Fuller test statistic } & -1.879977 & 0.6602 \\
\hline \multirow[t]{10}{*}{ Test critical values: } & \multicolumn{2}{|l|}{$1 \%$ level } & -4.017568 & \\
\hline & \multicolumn{2}{|l|}{$5 \%$ level } & -3.438700 & \\
\hline & \multicolumn{2}{|l|}{$10 \%$ level } & -3.143666 & \\
\hline & \multicolumn{4}{|c|}{ "MacKinnon (1996) one-sided p-values. } \\
\hline & \multicolumn{4}{|c|}{ Augmented Dickey-Fuller Test Equation } \\
\hline & \multicolumn{4}{|c|}{ Dependent Variable: D(USD_EUR) } \\
\hline & \multicolumn{4}{|c|}{ Method: Least Squares } \\
\hline & \multicolumn{4}{|c|}{ Date: 04/30/13 Time: $23: 55$} \\
\hline & \multicolumn{4}{|c|}{ Sample (adjusted): 2000M03 2013M03 } \\
\hline & \multicolumn{4}{|c|}{ Included observations: 157 after adjustments } \\
\hline Variable & Coefficient & Std. Error & t-Statistic & Prob. \\
\hline USD_EUR $(-1)$ & -0.037629 & 0.020016 & -1.879977 & 0.0620 \\
\hline D(USD_EUR (-1)) & 0.322964 & 0.076939 & 4.197673 & 0.0000 \\
\hline $\mathrm{C}$ & 0.001599 & 0.004044 & 0.395337 & 0.6931 \\
\hline @TREND(2000M01 & $8.38 \mathrm{E}-05$ & $7.31 \mathrm{E}-05$ & 1.146264 & 0.2535 \\
\hline R-squared & 0.114862 & \multicolumn{2}{|c|}{ Mean dependent var } & 0.001760 \\
\hline Adjusted R-squared & 0.097506 & \multicolumn{2}{|c|}{ S.D. dependent var } & 0.025432 \\
\hline S.E. of regression & 0.024161 & \multicolumn{2}{|c|}{ Akaike info criterion } & -4.583039 \\
\hline Sum squared resid & 0.089311 & \multicolumn{2}{|c|}{ Schwarz criterion } & -4.505172 \\
\hline Log likelihood & 363.7685 & \multicolumn{2}{|c|}{ Hannan-Quinn criter. } & -4.551414 \\
\hline F-statistic & 6.618140 & \multicolumn{2}{|c|}{ Durbin-Watson stat } & 1.906269 \\
\hline Prob (F-statistic) & \multicolumn{3}{|l|}{0.000311} & \\
\hline
\end{tabular}

Table 1.2.

Null Hypothesis: USD_EUR has a unit root

Exogenous: Constant

Lag Length: 1 (Automatic-based on SIC, maxlag =13)

\begin{tabular}{|c|c|c|}
\hline & t-Statistic & Prob. \\
\hline Augmented Dickey-Fuller test statistic & -1.627012 & 0.4664 \\
\hline $1 \%$ level & -3.472259 & \\
\hline $5 \%$ level & -2.879846 & \\
\hline $10 \%$ level & -2.576610 & \\
\hline
\end{tabular}




\begin{tabular}{|c|c|c|c|c|}
\hline \multicolumn{5}{|c|}{ "MacKinnon (1996) one-sided p-values. } \\
\hline \multicolumn{5}{|c|}{ Augmented Dickey-Fuller Test Equation } \\
\hline \multicolumn{5}{|c|}{ Dependent Variable: D(USD_EUR) } \\
\hline \multicolumn{5}{|c|}{ Method: Least Squares } \\
\hline \multicolumn{5}{|c|}{ Date: $05 / 01 / 13$ Time: $00: 03$} \\
\hline \multicolumn{5}{|c|}{ Sample (adjusted): 2000M03 2013M03 } \\
\hline \multicolumn{5}{|c|}{ Included observations: 157 after adjustments } \\
\hline Variable & Coefficient & Std. Error & t-Statistic & Prob. \\
\hline USD_EUR $(-1)$ & -0.018971 & 0.011660 & -1.627012 & 0.1058 \\
\hline D(USD_EUR $(-1))$ & 0.310732 & 0.076273 & 4.073951 & 0.0001 \\
\hline $\mathrm{C}$ & 0.004800 & 0.002927 & 1.640082 & 0.1030 \\
\hline R-squared & 0.107261 & \multicolumn{2}{|c|}{ Mean dependent var } & 0.001760 \\
\hline Adjusted R-squared & 0.095667 & \multicolumn{2}{|c|}{ S.D. dependent var } & 0.025432 \\
\hline S.E. of regression & 0.024185 & \multicolumn{2}{|c|}{ Akaike info criterion } & -4.587226 \\
\hline Sum squared resid & 0.090078 & \multicolumn{2}{|c|}{ Schwarz criterion } & -4.528827 \\
\hline Log likelihood & 363.0973 & \multicolumn{2}{|c|}{ Hannan-Quinn criter. } & -4.563508 \\
\hline F-statistic & 9.251392 & \multicolumn{2}{|c|}{ Durbin-Watson stat } & 1.906204 \\
\hline Prob (F-statistic) & 0.000161 & & & \\
\hline
\end{tabular}

Table 1.3.

Null Hypothesis: USD_EUR has a unit root

Exogenous: None

Lag Length: 1 (Automatic-based on SIC, maxlag =13)

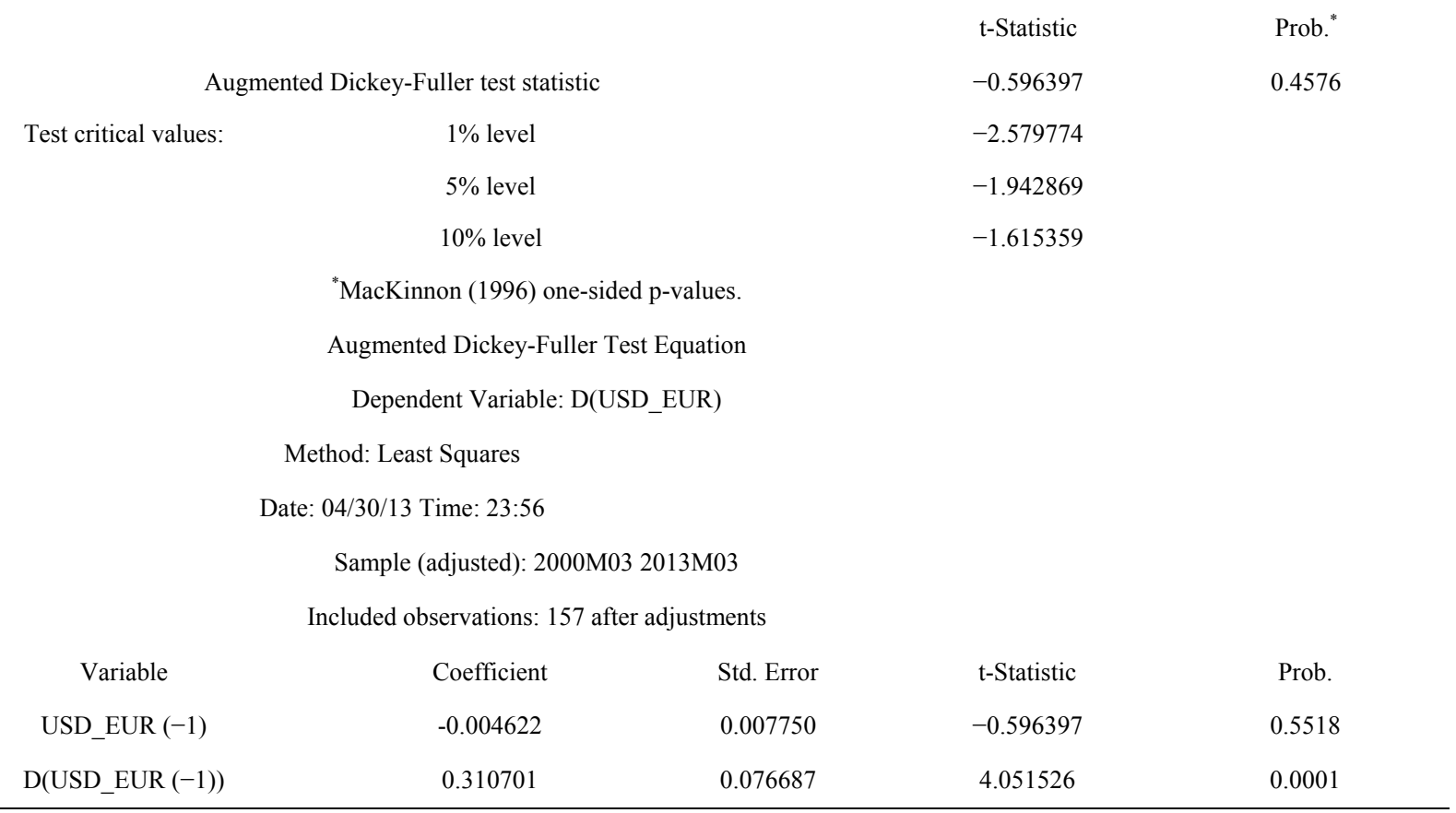




\section{Continued}

\begin{tabular}{cccc}
\hline R-squared & 0.091668 & Mean dependent var & 0.001760 \\
Adjusted R-squared & 0.085807 & S.D. dependent var & 0.025432 \\
S.E. of regression & 0.024317 & Akaike info criterion & -4.582649 \\
Sum squared resid & 0.091652 & Schwarz criterion & -4.543716 \\
Log likelihood & 361.7380 & Hannan-Quinn criter. & -4.566837 \\
Durbin-Watson stat & 1.901715 & & \\
\hline
\end{tabular}

Table 1.4.

Null Hypothesis: S has a unit root

Exogenous: Constant, Linear Trend

Lag Length: 0 (Automatic-based on SIC, maxlag = 13)

Augmented Dickey-Fuller test statistic

t-Statistic Prob.

$-9.104497$

0.0000

Test critical values:

$$
\begin{aligned}
& 1 \% \text { level } \\
& 5 \% \text { level } \\
& 10 \% \text { level }
\end{aligned}
$$$$
-4.017568
$$$$
-3.438700
$$$$
-3.143666
$$

* MacKinnon (1996) one-sided p-values.

Augmented Dickey-Fuller Test Equation

Dependent Variable: D(S)

Method: Least Squares

Date: 05/01/13 Time: 00:19

\begin{tabular}{|c|c|c|c|c|}
\hline Variable & Coefficient & Std. Error & t-Statistic & Prob. \\
\hline @)TREND(2000M01) & $-2.80 \mathrm{E}-05$ & $4.29 \mathrm{E}-05$ & -0.652052 & 0.5153 \\
\hline Adjusted R-squared & 0.341837 & \multicolumn{2}{|c|}{ S.D. dependent var } & 0.030025 \\
\hline S.E. of regression & 0.024359 & \multicolumn{2}{|c|}{ Akaike info criterion } & -4.572940 \\
\hline F-statistic & 41.51164 & \multicolumn{2}{|c|}{ Durbin-Watson stat } & 1.901343 \\
\hline Prob (F-statistic) & 0.000000 & & & \\
\hline
\end{tabular}

Sample (adjusted): 2000M03 2013M03

Included observations: 157 after adjustments 
Table 1.5.

Null Hypothesis: D(S) has a unit root

Exogenous: Constant

Lag Length: 2 (Automatic-based on SIC, maxlag = 13)

Augmented Dickey-Fuller test statistic

t-Statistic

Prob.

$-11.41115$

0.0000

Test critical values:

$1 \%$ level

$5 \%$ level

$10 \%$ level
$-3.473096$

$-2.880211$

$-2.576805$

*MacKinnon (1996) one-sided p-values.

Augmented Dickey-Fuller Test Equation

Dependent Variable: D(S,2)

Method: Least Squares

Date: 05/01/13 Time: 00:30

Sample (adjusted): 2000M06 2013M03

Included observations: 154 after adjustments

\begin{tabular}{|c|c|c|c|c|}
\hline Variable & Coefficient & Std. Error & t-Statistic & Prob. \\
\hline $\mathrm{D}(\mathrm{S}(-1))$ & -2.059546 & 0.180485 & -11.41115 & 0.0000 \\
\hline $\mathrm{D}(\mathrm{S}(-1), 2)$ & 0.647650 & 0.130722 & 4.954415 & 0.0000 \\
\hline $\mathrm{D}(\mathrm{S}(-2), 2)$ & 0.214490 & 0.080233 & 2.673330 & 0.0083 \\
\hline $\mathrm{C}$ & 0.000320 & 0.002176 & 0.147022 & 0.8833 \\
\hline R-squared & 0.685197 & \multicolumn{2}{|c|}{ Mean dependent var } & $-5.97 \mathrm{E}-05$ \\
\hline Adjusted R-squared & 0.678901 & \multicolumn{2}{|c|}{ S.D. dependent var } & 0.047635 \\
\hline S.E. of regression & 0.026993 & \multicolumn{2}{|c|}{ Akaike info criterion } & -4.360876 \\
\hline Sum squared resid & 0.109290 & \multicolumn{2}{|c|}{ Schwarz criterion } & -4.281994 \\
\hline Log likelihood & 339.7874 & \multicolumn{2}{|c|}{ Hannan-Quinn criter. } & -4.328834 \\
\hline F-statistic & 108.8297 & \multicolumn{2}{|c|}{ Durbin-Watson stat } & 1.958890 \\
\hline Prob (F-statistic) & 0.000000 & & & \\
\hline
\end{tabular}

Table 1.6.

Null Hypothesis: D(S) has a unit root

Exogenous: None

Lag Length: 2 (Automatic-based on SIC, maxlag = 13)

Augmented Dickey-Fuller test statistic

Test critical values:

$1 \%$ level

$5 \%$ level

$10 \%$ level
t-Statistic

Prob.

$-11.44760$

0.0000

$-2.580065$

$-1.942910$

$-1.615334$ 


\section{Continued}

\begin{tabular}{|c|c|c|c|c|}
\hline \multicolumn{5}{|c|}{ "MacKinnon (1996) one-sided p-values. } \\
\hline \multicolumn{5}{|c|}{ Augmented Dickey-Fuller Test Equation } \\
\hline \multicolumn{5}{|c|}{ Dependent Variable: $\mathrm{D}(\mathrm{S}, 2)$} \\
\hline \multicolumn{5}{|c|}{ Method: Least Squares } \\
\hline \multicolumn{5}{|c|}{ Date: $05 / 01 / 13$ Time: $00: 31$} \\
\hline \multicolumn{5}{|c|}{ Sample (adjusted): 2000M06 2013M03 } \\
\hline \multicolumn{5}{|c|}{ Included observations: 154 after adjustments } \\
\hline Variable & Coefficient & Std. Error & t-Statistic & Prob. \\
\hline $\mathrm{D}(\mathrm{S}(-1))$ & -2.059028 & 0.179865 & -11.44760 & 0.0000 \\
\hline $\mathrm{D}(\mathrm{S}(-1), 2)$ & 0.647283 & 0.130274 & 4.968635 & 0.0000 \\
\hline $\mathrm{D}(\mathrm{S}(-2), 2)$ & 0.214285 & 0.079961 & 2.679881 & 0.0082 \\
\hline R-squared & 0.685152 & \multicolumn{2}{|c|}{ Mean dependent var } & $-5.97 \mathrm{E}-05$ \\
\hline Adjusted R-squared & 0.680982 & \multicolumn{2}{|c|}{ S.D. dependent var } & 0.047635 \\
\hline S.E. of regression & 0.026905 & \multicolumn{2}{|c|}{ Akaike info criterion } & -4.373718 \\
\hline Sum squared resid & 0.109306 & \multicolumn{2}{|c|}{ Schwarz criterion } & -4.314557 \\
\hline Log likelihood & 339.7763 & \multicolumn{2}{|c|}{ Hannan-Quinn criter. } & -4.349687 \\
\hline Durbin-Watson stat & 1.958836 & & & \\
\hline
\end{tabular}

Table 1.1(b)

Null Hypothesis: USD_EUR_3MO has a unit root

Exogenous: Constant, Linear Trend

Lag Length: 1 (Automatic-based on SIC, maxlag = 13)

Augmented Dickey-Fuller test statistic

$$
\begin{array}{cc}
\text { Test critical values: } & 1 \% \text { level } \\
5 \% \text { level } \\
10 \% \text { level }
\end{array}
$$

t-Statistic

Prob.

$-1.853265$

0.6738

$-4.017568$

$-3.438700$

$-3.143666$

${ }^{*}$ MacKinnon (1996) one-sided p-values.

Augmented Dickey-Fuller Test Equation

Dependent Variable: D(USD_EUR_3MO)

Method: Least Squares

Date: 05/01/13 Time: 01:15

Sample (adjusted): 2000M03 2013M03

Included observations: 157 after adjustments

$\begin{array}{ccccc}\text { Variable } & \text { Coefficien } & \text { Std. Error } & \text { t-Statistic } & \text { Prob. } \\ \text { USD_EUR_3MO(-1) } & -0.037143 & 0.020042 & -1.853265 & 0.0658 \\ \text { D(USD_EUR_3MO(-1)) } & 0.312895 & 0.077209 & 4.052590 & 0.0001 \\ \text { C } & 0.001563 & 0.004049 & 0.385970 & 0.7001\end{array}$




\section{Continued}

\begin{tabular}{cccc} 
@TREND(2000M01) & $8.32 \mathrm{E}-05$ & $7.32 \mathrm{E}-05$ & 1.136803 \\
R-squared & 0.108380 & Mean dependent var & 0.2574 \\
Adjusted R-squared & 0.090898 & S.D. dependent var & 0.001721 \\
S.E. of regression & 0.024218 & Akaike info criterion & 0.025400 \\
Sum squared resid & 0.089736 & Schwarz criterion & -4.578301 \\
Log likelihood & 363.3967 & Hannan-Quinn criter. & -4.500435 \\
F-statistic & 6.199278 & Durbin-Watson stat & -4.546677 \\
Prob (F-statistic) & 0.000530 & & 1.907224 \\
\hline
\end{tabular}

\section{Table 1.2(b)}

Null Hypothesis: USD_EUR_3MO has a unit root

Exogenous: Constant

Lag Length: 1 (Automatic-based on SIC, maxlag = 13)

Augmented Dickey-Fuller test statistic

$\begin{array}{ll}\text { t-Statistic } & \text { Prob. }^{*} \\ -1.593227 & 0.4837\end{array}$

$$
\begin{aligned}
& \text { Test critical values: } \\
& 1 \% \text { level } \\
& 5 \% \text { level } \\
& 10 \% \text { level }
\end{aligned}
$$$$
-3.472259
$$

\begin{tabular}{|c|c|c|c|c|}
\hline Variable & Coefficient & Std. Error & t-Statistic & Prob. \\
\hline USD_EUR_3MO(-1) & -0.018630 & 0.011693 & -1.593227 & 0.1132 \\
\hline D(USD_EUR_3MO $(-1))$ & 0.300906 & 0.076558 & 3.930450 & 0.0001 \\
\hline $\mathrm{C}$ & 0.004733 & 0.002938 & 1.610995 & 0.1092 \\
\hline R-squared & 0.100849 & \multicolumn{2}{|c|}{ Mean dependent var } & 0.001721 \\
\hline Adjusted R-squared & 0.089172 & \multicolumn{2}{|c|}{ S.D. dependent var } & 0.025400 \\
\hline S.E. of regression & 0.024241 & \multicolumn{2}{|c|}{ Akaike info criterion } & -4.582629 \\
\hline Sum squared resid & 0.090494 & \multicolumn{2}{|c|}{ Schwarz criterion } & -4.524229 \\
\hline Log likelihood & 362.7364 & \multicolumn{2}{|c|}{ Hannan-Quinn criter. } & -4.558911 \\
\hline F-statistic & 8.636363 & \multicolumn{2}{|c|}{ Durbin-Watson stat } & 1.907614 \\
\hline Prob(F-statistic) & 0.000279 & & & \\
\hline
\end{tabular}$$
-2.879846
$$

Method: Least Squares

Date: 05/01/13 Time: 01:16

Sample (adjusted): 2000M03 2013M03

Included observations: 157 after adjustments 
Table 1.3(b)

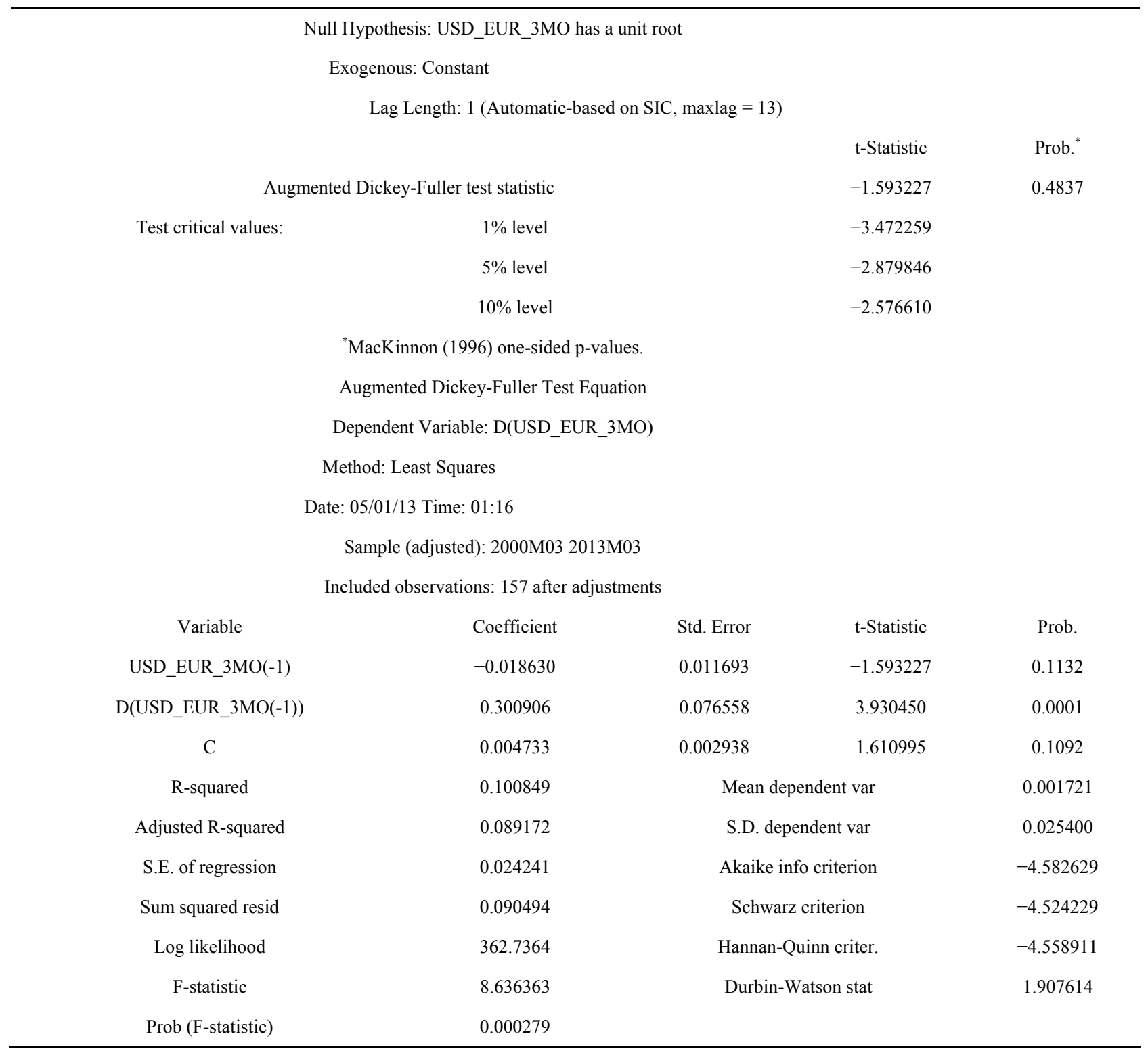

Table 1.4(b)

Null Hypothesis: F has a unit root

Exogenous: Constant, Linear Trend

Lag Length: 0 (Automatic-based on SIC, maxlag =13)

$\begin{array}{rcc} & \text { t-Statistic } & \text { Prob. }^{*} \\ \text { Augmented Dickey-Fuller test statistic } & -9.200100 & 0.0000 \\ 1 \% \text { level } & -4.017568 \\ 5 \% \text { level } & -3.438700 \\ 10 \% \text { level } & -3.143666\end{array}$

${ }^{*}$ MacKinnon (1996) one-sided p-values.

Augmented Dickey-Fuller Test Equation 


\begin{tabular}{|c|c|c|c|c|}
\hline \multicolumn{5}{|c|}{ Dependent Variable: $\mathrm{D}(\mathrm{F})$} \\
\hline \multicolumn{5}{|c|}{ Method: Least Squares } \\
\hline \multicolumn{5}{|c|}{ Date: $05 / 01 / 13$ Time: $01: 24$} \\
\hline \multicolumn{5}{|c|}{ Sample (adjusted): 2000M03 2013M03 } \\
\hline \multicolumn{5}{|c|}{ Included observations: 157 after adjustments } \\
\hline Variable & Coefficient & Std. Error & t-Statistic & Prob. \\
\hline $\mathrm{F}(-1)$ & -0.708141 & 0.076971 & -9.200100 & 0.0000 \\
\hline $\mathrm{C}$ & 0.003380 & 0.003959 & 0.853816 & 0.3945 \\
\hline @TREND(2000M01) & $-2.70 \mathrm{E}-05$ & $4.30 \mathrm{E}-05$ & -0.628238 & 0.5308 \\
\hline R-squared & 0.355022 & \multicolumn{2}{|c|}{ Mean dependent var } & $6.96 \mathrm{E}-07$ \\
\hline Adjusted R-squared & 0.346645 & \multicolumn{2}{|c|}{ S.D. dependent var } & 0.030197 \\
\hline S.E. of regression & 0.024409 & \multicolumn{2}{|c|}{ Akaike info criterion } & -4.568840 \\
\hline Sum squared resid & 0.091750 & \multicolumn{2}{|c|}{ Schwarz criterion } & -4.510441 \\
\hline Log likelihood & 361.6539 & \multicolumn{2}{|c|}{ Hannan-Quinn criter. } & -4.545122 \\
\hline F-statistic & 42.38388 & \multicolumn{2}{|c|}{ Durbin-Watson stat } & 1.903271 \\
\hline Prob (F-statistic) & 0.000000 & & & \\
\hline
\end{tabular}

Table 1.5(b)

Null Hypothesis: F has a unit root

Exogenous: Constant

Lag Length: 0 (Automatic-based on SIC, maxlag = 13)

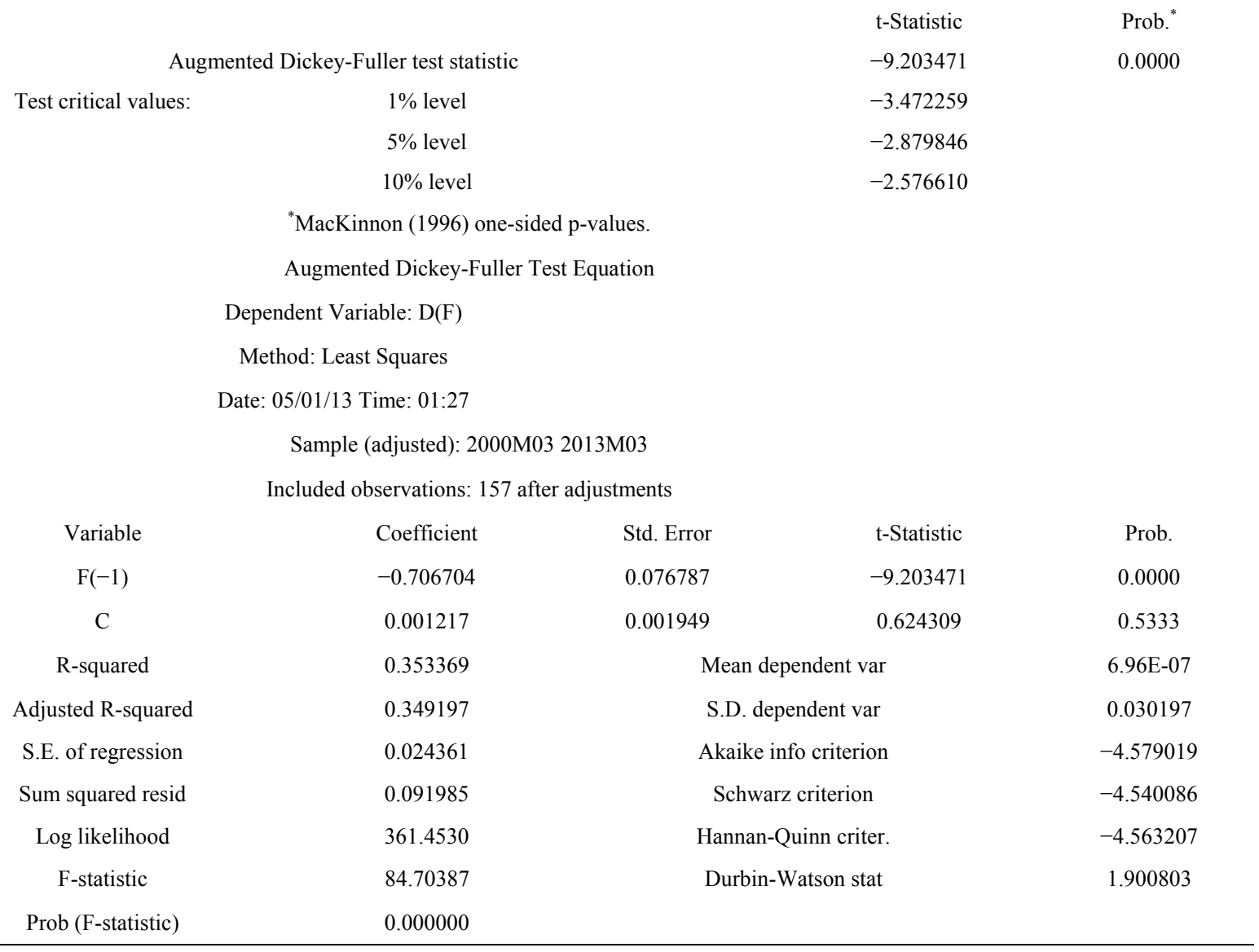


Table 1.6(b)

Null Hypothesis: F has a unit root

Exogenous: None

Lag Length: 0 (Automatic-based on SIC, maxlag =13)

\section{Augmented Dickey-Fuller test statistic}

Test critical values:

$$
\begin{aligned}
& \text { t-Statistic } \\
& -9.200284 \\
& -2.579774 \\
& -1.942869 \\
& -1.615359
\end{aligned}
$$

Prob.

0.0000

$$
\begin{aligned}
& 5 \% \text { level } \\
& 10 \% \text { level }
\end{aligned}
$$

*MacKinnon (1996) one-sided p-values.

Augmented Dickey-Fuller Test Equation

Dependent Variable: D(F)

Method: Least Squares

Date: 05/01/13 Time: 01:28

Sample (adjusted): 2000M03 2013M03

Included observations: 157 after adjustments

$\begin{array}{cccc}\text { Variable } & \text { Coefficient } & \text { Std. Error } & \text { t-Statistic } \\ \text { F(-1) } & -0.703454 & 0.076460 & -9.200284 \\ \text { R-squared } & 0.351743 & \text { Mean dependent var } & 6.0000 \\ \text { Adjusted R-squared } & 0.351743 & \text { S.D. dependent var } & 0.030197 \\ \text { S.E. of regression } & 0.024313 & \text { Akaike info criterion } & -4.589247 \\ \text { Sum squared resid } & 0.092216 & \text { Schwarz criterion } & -4.569780 \\ \text { Log likelihood } & 361.2559 & \text { Hannan-Quinn criter. } & -4.581341 \\ \text { Durbin-Watson stat } & 1.901439 & \end{array}$

\section{KPSS tests:}

Table 2.1. 


\begin{tabular}{|c|c|c|c|c|}
\hline \multicolumn{5}{|c|}{ Dependent Variable: USD_EUR } \\
\hline \multicolumn{5}{|c|}{ Method: Least Squares } \\
\hline \multicolumn{5}{|c|}{ Date: 05/01/13 Time: 01:33 } \\
\hline \multicolumn{5}{|c|}{ Sample: 2000M01 2013M03 } \\
\hline \multicolumn{5}{|c|}{ Included observations: 159} \\
\hline Variable & Coefficient & Std. Error & t-Statistic & Prob. \\
\hline $\mathrm{C}$ & -0.041448 & 0.015527 & -2.669403 & 0.0084 \\
\hline @TREND(2000M01) & 0.002909 & 0.000170 & 17.11939 & 0.0000 \\
\hline R-squared & 0.651168 & \multicolumn{2}{|c|}{ Mean dependent var } & 0.188391 \\
\hline Adjusted R-squared & 0.648946 & \multicolumn{2}{|c|}{ S.D. dependent var } & 0.166004 \\
\hline S.E. of regression & 0.098357 & \multicolumn{2}{|c|}{ Akaike info criterion } & -1.787927 \\
\hline Sum squared resid & 1.518834 & \multicolumn{2}{|c|}{ Schwarz criterion } & -1.749324 \\
\hline Log likelihood & 144.1402 & \multicolumn{2}{|c|}{ Hannan-Quinn criter. } & -1.772251 \\
\hline F-statistic & 293.0734 & \multicolumn{2}{|c|}{ Durbin-Watson stat } & 0.067298 \\
\hline Prob (F-statistic) & 0.000000 & & & \\
\hline
\end{tabular}

Table 2.2.

Null Hypothesis: $\mathrm{S}$ is stationary

Exogenous: Constant, Linear Trend

Bandwidth: 1 (Newey-West automatic) using Bartlett kernel

Kwiatkowski-Phillips-Schmidt-Shin test statistic

LM-Stat.

0.079840

Asymptotic critical values*:

$1 \%$ level
$5 \%$ level

0.216000

0.146000

0.119000

${ }^{*}$ Kwiatkowski-Phillips-Schmidt-Shin (1992, Table 1)

Residual variance (no correction)

0.000644

HAC corrected variance (Bartlett kernel)

0.000836

KPSS Test Equation

Dependent Variable: S

Method: Least Squares

Date: 05/01/13 Time: 01:51

Sample (adjusted): 2000M02 2013M03

Included observations: 158 after adjustments

\begin{tabular}{|c|c|c|c|c|}
\hline Variable & Coefficient & Std. Error & $\mathrm{t}$-Statistic & Prob. \\
\hline $\mathrm{C}$ & 0.003549 & 0.004082 & 0.869288 & 0.3860 \\
\hline @TREND(2000M01) & $-2.51 \mathrm{E}-05$ & $4.45 \mathrm{E}-05$ & -0.562515 & 0.5746 \\
\hline R-squared & 0.002024 & \multicolumn{2}{|c|}{ Mean dependent var } & 0.001557 \\
\hline Adjusted R-squared & -0.004373 & \multicolumn{2}{|c|}{ S.D. dependent var } & 0.025480 \\
\hline S.E. of regression & 0.025535 & \multicolumn{2}{|c|}{ Akaike info criterion } & -4.484941 \\
\hline Sum squared resid & 0.101719 & \multicolumn{2}{|c|}{ Schwarz criterion } & -4.446174 \\
\hline Log likelihood & 356.3103 & \multicolumn{2}{|c|}{ Hannan-Quinn criter. } & -4.469197 \\
\hline F-statistic & 0.316423 & \multicolumn{2}{|c|}{ Durbin-Watson stat } & 1.382589 \\
\hline Prob (F-statistic) & 0.574573 & & & \\
\hline
\end{tabular}


Table 2.3.

\begin{tabular}{|c|c|c|c|c|}
\hline \multicolumn{4}{|c|}{ Null Hypothesis: $\mathrm{S}$ is stationary } & \\
\hline \multicolumn{5}{|c|}{ Exogenous: Constant } \\
\hline \multicolumn{5}{|c|}{ Bandwidth: 2 (Newey-West automatic) using Bartlett kernel } \\
\hline & LM-Stat. \\
\hline \multicolumn{4}{|c|}{ Kwiatkowski-Phillips-Schmidt-Shin test statistic } & 0.116265 \\
\hline \multirow{3}{*}{\multicolumn{2}{|c|}{ Asymptotic critical values*: }} & $1 \%$ level & & 0.739000 \\
\hline & & $5 \%$ level & & 0.463000 \\
\hline & & $10 \%$ level & & 0.347000 \\
\hline \multicolumn{5}{|c|}{ "Kwiatkowski-Phillips-Schmidt-Shin (1992, Table 1) } \\
\hline \multicolumn{4}{|c|}{ Residual variance (no correction) } & 0.000645 \\
\hline \multicolumn{4}{|c|}{ HAC corrected variance (Bartlett kernel) } & 0.000881 \\
\hline \multicolumn{5}{|c|}{ KPSS Test Equation } \\
\hline \multicolumn{5}{|c|}{ Dependent Variable: S } \\
\hline \multicolumn{5}{|c|}{ Method: Least Squares } \\
\hline \multicolumn{5}{|c|}{ Date: 05/01/13 Time: 01:52 } \\
\hline \multicolumn{5}{|c|}{ Sample (adjusted): 2000M02 2013M03 } \\
\hline \multicolumn{5}{|c|}{ Included observations: 158 after adjustments } \\
\hline Variable & Coefficient & Std. Error & t-Statistic & Prob. \\
\hline $\mathrm{C}$ & 0.001557 & 0.002027 & 0.768046 & 0.4436 \\
\hline R-squared & 0.000000 & \multicolumn{2}{|c|}{ Mean dependent var } & 0.001557 \\
\hline Adjusted R-squared & 0.000000 & \multicolumn{2}{|c|}{ S.D. dependent var } & 0.025480 \\
\hline S.E. of regression & 0.025480 & \multicolumn{2}{|c|}{ Akaike info criterion } & -4.495573 \\
\hline Sum squared resid & 0.101926 & \multicolumn{2}{|c|}{ Schwarz criterion } & -4.476189 \\
\hline Log likelihood & 356.1503 & \multicolumn{2}{|c|}{ Hannan-Quinn criter. } & -4.487701 \\
\hline Durbin-Watson stat & 1.379790 & & & \\
\hline
\end{tabular}

Table 2.1(b)

Null Hypothesis: USD_EUR_3MO is stationary

Exogenous: Constant, Linear Trend

Bandwidth: 10 (Newey-West automatic) using Bartlett kernel

LM-Stat.

Kwiatkowski-Phillips-Schmidt-Shin test statistic

0.295846

Asymptotic critical values*:

$\begin{array}{ll}1 \% \text { level } & 0.216000 \\ 5 \% \text { level } & 0.146000 \\ 10 \% \text { level } & 0.119000\end{array}$

*Kwiatkowski-Phillips-Schmidt-Shin (1992, Table 1)

$\begin{array}{ll}\text { Residual variance (no correction) } & 0.009573\end{array}$

HAC corrected variance (Bartlett kernel)

0.085773 


\section{Continued}

\begin{tabular}{|c|c|c|c|c|}
\hline \multicolumn{5}{|c|}{ KPSS Test Equation } \\
\hline \multicolumn{5}{|c|}{ Dependent Variable: USD_EUR_3MO } \\
\hline \multicolumn{5}{|c|}{ Method: Least Squares } \\
\hline \multicolumn{5}{|c|}{ Date: $05 / 01 / 13$ Time: $02: 02$} \\
\hline \multicolumn{5}{|c|}{ Sample: 2000M01 2013M03 } \\
\hline \multicolumn{5}{|c|}{ Included observations: 159} \\
\hline Variable & Coefficient & Std. Error & t-Statistic & Prob. \\
\hline $\mathrm{C}$ & -0.040650 & 0.015544 & -2.615208 & 0.0098 \\
\hline @TREND(2000M01) & 0.002905 & 0.000170 & 17.07396 & 0.0000 \\
\hline R-squared & 0.649960 & \multicolumn{2}{|c|}{ Mean dependent var } & 0.188823 \\
\hline Adjusted R-squared & 0.647730 & \multicolumn{2}{|c|}{ S. D. dependent var } & 0.165893 \\
\hline S.E. of regression & 0.098461 & \multicolumn{2}{|c|}{ Akaike info criterion } & -1.785808 \\
\hline Sum squared resid & 1.522056 & \multicolumn{2}{|c|}{ Schwarz criterion } & -1.747205 \\
\hline Log likelihood & 143.9717 & \multicolumn{2}{|c|}{ Hannan-Quinn criter. } & -1.770132 \\
\hline F-statistic & 291.5201 & \multicolumn{2}{|c|}{ Durbin-Watson stat } & 0.066965 \\
\hline Prob (F-statistic) & 0.000000 & & & \\
\hline
\end{tabular}

Table 2.2(b)

\begin{tabular}{|c|c|c|c|c|}
\hline \multicolumn{4}{|c|}{ Null Hypothesis: F is stationary } & \\
\hline \multicolumn{5}{|c|}{ Exogenous: Constant, Linear Trend } \\
\hline \multicolumn{5}{|c|}{ Bandwidth: 1 (Newey-West automatic) using Bartlett kernel } \\
\hline \multirow{2}{*}{\multicolumn{4}{|c|}{ Kwiatkowski-Phillips-Schmidt-Shin test statistic }} & LM-Stat. \\
\hline & & & & 0.083098 \\
\hline \multirow{3}{*}{\multicolumn{2}{|c|}{ Asymptotic critical values ${ }^{*}:$}} & $1 \%$ level & & 0.216000 \\
\hline & & $5 \%$ level & & 0.146000 \\
\hline & & $10 \%$ level & & 0.119000 \\
\hline \multicolumn{5}{|c|}{ "Kwiatkowski-Phillips-Schmidt-Shin (1992, Table 1) } \\
\hline \multicolumn{4}{|c|}{ Residual variance (no correction) } & 0.000642 \\
\hline \multicolumn{4}{|c|}{ HAC corrected variance (Bartlett kernel) } & 0.000828 \\
\hline \multicolumn{5}{|c|}{ KPSS Test Equation } \\
\hline \multicolumn{5}{|c|}{ Dependent Variable: F } \\
\hline \multicolumn{5}{|c|}{ Method: Least Squares } \\
\hline \multicolumn{5}{|c|}{ Date: 05/01/13 Time: 02:10 } \\
\hline \multicolumn{5}{|c|}{ Sample (adjusted): 2000M02 2013M03 } \\
\hline \multicolumn{5}{|c|}{ Included observations: 158 after adjustments } \\
\hline Variable & Coefficient & Std. Error & $\mathrm{t}$-Statistic & Prob. \\
\hline $\mathrm{C}$ & 0.003412 & 0.004077 & 0.836966 & 0.4039 \\
\hline @TREND(2000M01) & $-2.38 \mathrm{E}-05$ & $4.45 \mathrm{E}-05$ & -0.534336 & 0.5939 \\
\hline R-squared & 0.001827 & \multicolumn{2}{|c|}{ Mean dependent var } & 0.001523 \\
\hline Adjusted R-squared & -0.004572 & \multicolumn{2}{|c|}{ S. D. dependent var } & 0.025442 \\
\hline S.E. of regression & 0.025500 & \multicolumn{2}{|c|}{ Akaike info criterion } & -4.487725 \\
\hline Sum squared resid & 0.101436 & \multicolumn{2}{|c|}{ Schwarz criterion } & -4.448958 \\
\hline Log likelihood & 356.5303 & \multicolumn{2}{|c|}{ Hannan-Quinn criter. } & -4.471981 \\
\hline F-statistic & 0.285515 & \multicolumn{2}{|c|}{ Durbin-Watson stat } & 1.402386 \\
\hline Prob (F-statistic) & 0.593870 & & & \\
\hline
\end{tabular}


Table 2.3(b)

Null Hypothesis: $\mathrm{F}$ is stationary

Exogenous: Constant

Bandwidth: 1 (Newey-West automatic) using Bartlett kernel

LM-Stat.

Kwiatkowski-Phillips-Schmidt-Shin test statistic

0.122854

Asymptotic critical values*:

$$
\begin{aligned}
& 1 \% \text { level } \\
& 5 \% \text { level } \\
& 10 \% \text { level }
\end{aligned}
$$

0.739000

0.463000

0.347000

*Kwiatkowski-Phillips-Schmidt-Shin (1992, Table 1)

Residual variance (no correction)

0.000643

HAC corrected variance (Bartlett kernel)

0.000830

\section{KPSS Test Equation}

Dependent Variable: F

Method: Least Squares

Date: 05/01/13 Time: 02:12

\begin{tabular}{|c|c|c|c|c|}
\hline Variable & Coefficient & Std. Error & t-Statistic & Prob. \\
\hline $\mathrm{C}$ & 0.001523 & 0.002024 & 0.752250 & 0.4530 \\
\hline R-squared & 0.000000 & \multicolumn{2}{|c|}{ Mean dependent var } & 0.001523 \\
\hline Adjusted R-squared & 0.000000 & \multicolumn{2}{|c|}{ S.D. dependent var } & 0.025442 \\
\hline S.E. of regression & 0.025442 & \multicolumn{2}{|c|}{ Akaike info criterion } & -4.498554 \\
\hline Sum squared resid & 0.101622 & \multicolumn{2}{|c|}{ Schwarz criterion } & -4.479171 \\
\hline Log likelihood & 356.3858 & \multicolumn{2}{|c|}{ Hannan-Quinn criter. } & -4.490683 \\
\hline Durbin-Watson stat & 1.399823 & & & \\
\hline
\end{tabular}

Sample (adjusted): 2000M02 2013M03

Included observations: 158 after adjustments

\section{Zivot-Andrews Break Point Tests:}

Table 3.1.

Zivot-Andrews Unit Root Test

Date: 05/01/13 Time: 03:05

Sample: 2000M01 2013M03

Included observations: 159

Null Hypothesis: USD_EUR has a unit root with a structural break in both the intercept and trend

Chosen lag length: 2 (maximum lags: 4)

Chosen break point: 2008M08

$\begin{array}{lcc} & \text { t-Statistic } & \text { Prob. }^{*} \\ \text { Zivot-Andrews test statistic } & -3.991058 & 0.016963 \\ 1 \% \text { critical value: } & -5.57 & \\ 5 \% \text { critical value: } & -5.08 & \\ 10 \% \text { critical value: } & -4.82 & \end{array}$

* Probability values are calculated from a standard t-distribution and do not take into account the breakpoint selection process. 
Table 4.1.

\begin{tabular}{|c|c|c|c|c|}
\hline \multicolumn{5}{|c|}{ Dependent Variable: USD_EUR } \\
\hline \multicolumn{5}{|c|}{ Method: Least Squares } \\
\hline \multicolumn{5}{|c|}{ Date: $05 / 01 / 13$ Time: $03: 14$} \\
\hline \multicolumn{5}{|c|}{ Sample (adjusted): 2000M04 2013M03 } \\
\hline \multicolumn{5}{|c|}{ Included observations: 156 after adjustments } \\
\hline Variable & Coefficient & Std. Error & t-Statistic & Prob. \\
\hline $\mathrm{C}$ & 0.016163 & 0.006128 & 2.637689 & 0.0092 \\
\hline USD_EUR_3MO(-3) & 0.941235 & 0.024469 & 38.46685 & 0.0000 \\
\hline R-squared & 0.905735 & \multicolumn{2}{|c|}{ Mean dependent var } & 0.192267 \\
\hline Adjusted R-squared & 0.905123 & \multicolumn{2}{|c|}{ S.D. dependent var } & 0.165170 \\
\hline S.E. of regression & 0.050876 & \multicolumn{2}{|c|}{ Akaike info criterion } & -3.106122 \\
\hline Sum squared resid & 0.398605 & \multicolumn{2}{|c|}{ Schwarz criterion } & -3.067022 \\
\hline Log likelihood & 244.2775 & \multicolumn{2}{|c|}{ Hannan-Quinn criter. } & -3.090241 \\
\hline F-statistic & 1479.699 & \multicolumn{2}{|c|}{ Durbin-Watson stat } & 0.482103 \\
\hline Prob (F-statistic) & 0.000000 & & & \\
\hline
\end{tabular}

Table 4.1(b)

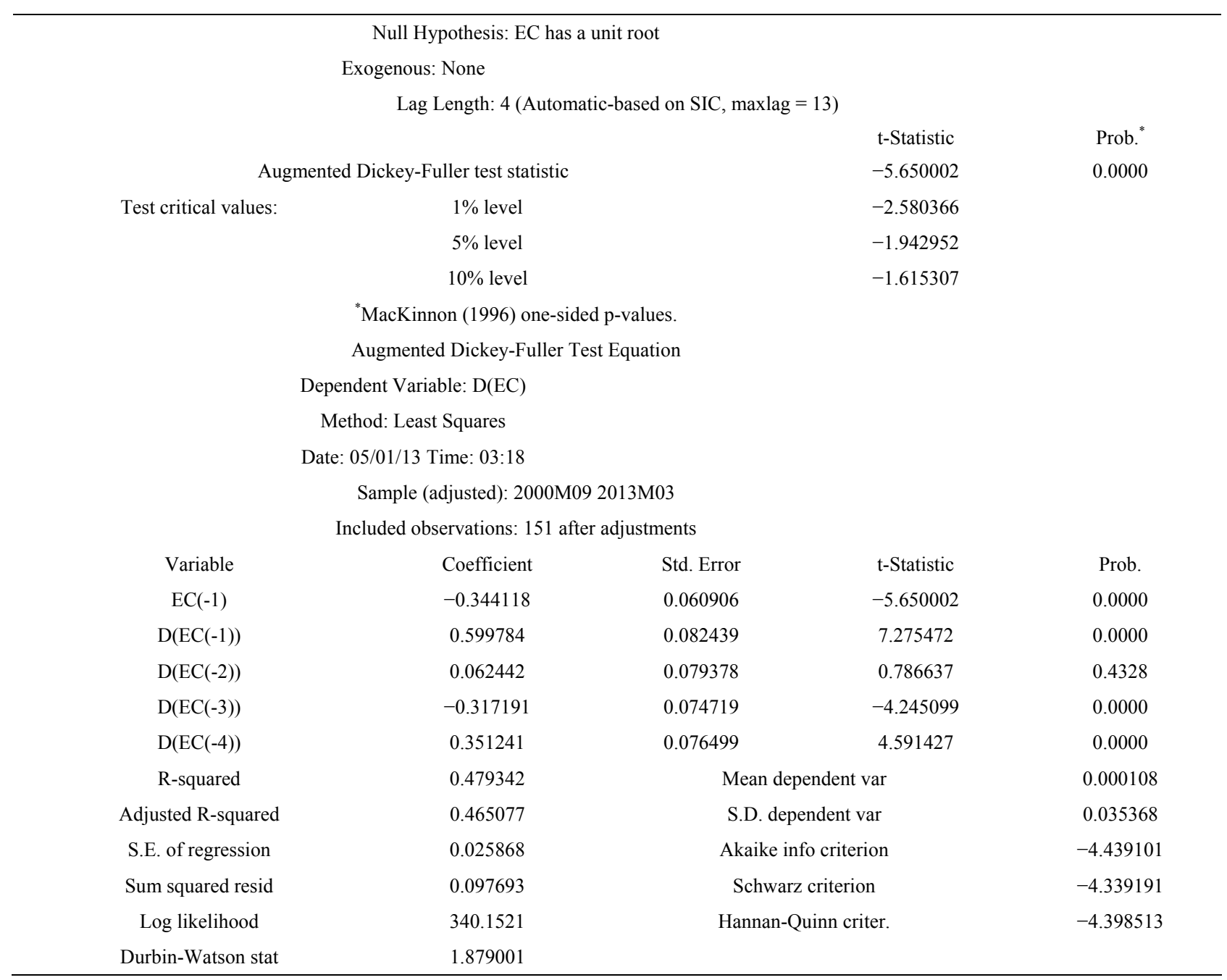


Table 4.2.

\begin{tabular}{|c|c|c|c|c|}
\hline \multicolumn{5}{|c|}{ Dependent Variable: USD_EUR } \\
\hline \multicolumn{5}{|c|}{ Method: Least Squares } \\
\hline \multicolumn{5}{|c|}{ Date: $05 / 01 / 13$ Time: $03: 12$} \\
\hline \multicolumn{5}{|c|}{ Sample (adjusted): 2000M04 2013M03 } \\
\hline \multicolumn{5}{|c|}{ Included observations: 159} \\
\hline Variable & Coefficient & Std. Error & t-Statistic & Prob. \\
\hline $\mathrm{C}$ & 0.000525 & 0.000377 & -1.391272 & 0.1661 \\
\hline USD_EUR_3MO & 1.000492 & 0.001502 & 666.1035 & 0.0000 \\
\hline R-squared & 0.999646 & \multicolumn{2}{|c|}{ Mean dependent var } & 0.188391 \\
\hline Adjusted R-squared & 0.999644 & \multicolumn{2}{|c|}{ S.D. dependent var } & 0.166004 \\
\hline S.E. of regression & 0.003132 & \multicolumn{2}{|c|}{ Akaike info criterion } & -8.681760 \\
\hline Sum squared resid & 0.001540 & \multicolumn{2}{|c|}{ Schwarz criterion } & -8.643158 \\
\hline Log likelihood & 692.1999 & \multicolumn{2}{|c|}{ Hannan-Quinn criter. } & -8.666084 \\
\hline F-statistic & 443693.9 & \multicolumn{2}{|c|}{ Durbin-Watson stat } & 0.157920 \\
\hline Prob (F-statistic) & 0.000000 & & & \\
\hline
\end{tabular}

Table 4.2(b)

Null Hypothesis: EC2 has a unit root

Exogenous: None

Lag Length: 1 (Automatic-based on SIC, maxlag = 13)

\begin{tabular}{lcr}
\multicolumn{1}{c}{ Augmented Dickey-Fuller test statistic } & t-Statistic \\
Test critical values: & -2.402287 \\
& $1 \%$ level & -2.579774 \\
$5 \%$ level & -1.942869 \\
$10 \%$ level & -1.615359
\end{tabular}

*MacKinnon (1996) one-sided p-values.

Augmented Dickey-Fuller Test Equation

Dependent Variable: D(EC2)

Method: Least Squares

Date: 05/01/13 Time: 03:21

Sample (adjusted): 2000M03 2013M03

Included observations: 157 after adjustments

\begin{tabular}{|c|c|c|c|c|}
\hline Variable & Coefficient & Std. Error & t-Statistic & Prob. \\
\hline $\mathrm{EC} 2(-1)$ & -0.073882 & 0.030755 & -2.402287 & 0.0175 \\
\hline $\mathrm{D}(\mathrm{EC} 2(-1))$ & -0.254660 & 0.076717 & -3.319472 & 0.0011 \\
\hline R-squared & 0.114773 & \multicolumn{2}{|c|}{ Mean dependent var } & $3.80 \mathrm{E}-05$ \\
\hline Adjusted R-squared & 0.109062 & \multicolumn{2}{|c|}{ S.D. dependent var } & 0.001247 \\
\hline S.E. of regression & 0.001177 & \multicolumn{2}{|c|}{ Akaike info criterion } & -10.63914 \\
\hline Sum squared resid & 0.000215 & \multicolumn{2}{|c|}{ Schwarz criterion } & -10.60020 \\
\hline Log likelihood & 837.1723 & \multicolumn{2}{|c|}{ Hannan-Quinn criter. } & -10.62332 \\
\hline Durbin-Watson stat & 2.064020 & & & \\
\hline
\end{tabular}

